\title{
Ticks and tick-borne pathogens in popular recreational areas in Tallinn, Estonia: an underestimated risk of tick-borne diseases
}

\author{
Maria Vikentjeva \\ National Institute for Health Development: Tervise Arengu Instituut \\ Olga Bragina \\ National Institute for Health Development: Tervise Arengu Instituut \\ Julia Geller ( $\square$ julia.geller@tai.ee ) \\ Tervise Arengu Instituut https://orcid.org/0000-0001-6496-9687
}

\section{Research}

Keywords: ticks, Borrelia, urban, tick-borne pathogen, tick-borne encephalitis virus, Borrelia miyamotoi, Neoehrlichia mikurensis, Anaplasma, Rickettsia

Posted Date: May 25th, 2021

DOI: https://doi.org/10.21203/rs.3.rs-543083/v1

License: (c) (i) This work is licensed under a Creative Commons Attribution 4.0 International License. Read Full License 


\section{Abstract \\ BACKGROUND}

For over several decades ticks are noticed to be widely present in the green spaces of urban environments. Rodents that provide essential bloodmeals for subadult ticks and serve as natural reservoirs for many known tick-borne diseases, such as Lyme borreliosis and tick-borne encephalitis, might be quite abundant in green areas within urban settlements. In that way, the improvement of green infrastructures within cities possess not only to better human well-being but might also increase the risk of being bitten by a tick and having a tick-borne disease. This study aimed to provide a first insight into ticks and tick-borne pathogen presence and prevalence in popular recreational green areas in Tallinn, Estonia.

\section{METHODS}

Ticks were collected by flagging in May-June, 2018. Tick species identification was performed on morphological criteria. Tick-borne pathogens detection was performed by pathogen-specific PCR and qPCR reactions.

\section{RESULTS}

855 Ixodes ticks were collected from a total area of $12000 \mathrm{~m}^{2}$. An estimated tick abundance were up to 18.5 ticks per $100 \mathrm{~m}^{2} .34 .3 \%$ of all ticks were revealed positive for at least one tick-borne pathogen. Borrelia burgdorferi s.l. was found in 17.5\%, Rickettsia sp in 13.8\%, Neoehrlichia mikurensis on $5.4 \%$, B. miyamotoi in $2.5 \%$, Anaplasma phagocytophilum in $0.6 \%$ and tick-borne encephalitis virus in $0.5 \%$ of ticks.

\section{CONCLUSION}

This study reports the occurrence of Ixodes tick species in popular recreational, outdoor sports and leisure areas in the largest city of Estonia, with abundance and prevalence rates compatible or even exceeding those detected previously in the most endemic foci in the natural environments. Taking into account increasing Lyme borreliosis incidence, the risk of acquiring a tick bite and being infected with a tick-borne disease in urban recreational sites should not be ignored and proper information about the precautions might be considered.

\section{Backround}

Ticks, especially those belonging to Ixodes ricinus complex, are among the most medically important vectors for various diseases in the Northern Hemisphere. Traditionally the risk of a tick bite followed by Lyme borreliosis (LB) or tick-borne encephalitis (TBE) has been associated with deciduous or mixed boreal forests, pastures and meadows [1]. The development of green infrastructures such as parks, recreational and leisure zones, outdoor sports facilities and health trails within the cities improve citizen attraction towards outdoor activities but also increases the risk for various zoonotic and vector-borne diseases.

Ticks are widely present in the green spaces of the urban environments even despite a low local floral and faunal diversity. Many rodent species, that are essential blood-meal providers for larval and nymphal ticks and reservoirs for tick-borne pathogens (TBPs) such as Borrelia burgdorferi sensu lato (BBSL) and tick-borne encephalitis virus (TBEV), are highly established in urban areas, well adapted to anthropogenic pressure and may thus play a role in the increasing incidence of tick-borne diseases (TBDs) in cities. Moreover, urban heat island effect may reflect positively on arthropods sensitive to cold temperatures by promoting their survival and shortening developmental diapause periods [2]. Several studies from Europe report the detection of various TBPs in ticks found within cities: TBEV, BBSL, B. miyamotoi, Neoehrlichia mikurensis, Anaplasma phagocytophilum and Rickettsia helvetica $[3,4,5]$. Therefore, urban green areas introduce a potential risk not only for acquiring a tick bite but also for TBDs.

Estonia has been an endemic area for TBE and LB for decades, reaching oppositely record incidence rates values by 2020 . While the incidence of TBE fell almost threefold to its lowest of the last 20 years rate of 5.1 cases per 100000 population, the number of LB cases was a record high comparing the same period - 182.1 cases per 100000 population, which is three times higher for compared to 2013 levels [6]. Still, about $15 \%$ of confirmed TBD-infected individuals with assumable geographical origin of a tick bite, were reported within urban areas [7]. Two non-nidicolous Ixodes tick species of medical importance, I. ricinus and I. persulcatus have been shown to maintain the circulation of various TBPs in Estonia. In addition to European (TBEV-Eu) and Siberian (TBEV-Sib) TBEV subtypes, at least five species of BBSL, as well as various TBPs including tickborne Rickettsiales (A. phagocytophilum, Ehrlichia muris, N. mikurensis, R. helvetica, R. monacensis, Ca. R. tarasevichae), relapsing fever group $B$. miyamotoi and several Babesia species have been detected in questing ticks in their natural habitats $[8,9,10,11,12,13,14]$.

This study provides the first insight into ticks and TBPs distribution within urban areas in the city of Tallinn by investigating the presence and abundance of ticks and analysis of the taxonomic content of tick-borne pathogens in the popular recreational areas and leisure sites located 
within the city and in the nearest peri-urban surroundings.

\section{Materials And Methods Study areas selection and tick collection sites}

Two main aspects were considered when choosing study areas: suitable habitats for ticks and popularity among visitors. Satellite imagery from Google Earth and Estonian Land Board Web Map application (xgis.maaamet.ee/maps), as well as personal observations and data on recreational areas from the official Tallinn webpage (www.tallinn.ee) were used for initial identification of potentially suitable study areas which were then visited to determine specific flagging sites. Urban areas were selected according to the presence of bushes, broad-leaf or temperate forested area and a litter layer. Peri-urban collection sites were situated mostly in deciduous forests or their edges, with known recreational popularity among visitors. According to observations, 17 urban and 3 peri-urban areas were selected in collaboration with the respective authorities where applicable (Fig. 1). Each transect was located along trails or their closest proximity to imitate visitors' behavior as closely as possible. The observations and variables recorded at each site included date, time, transect length passed and air temperature. Habitat and vegetation type as well signs of any host presence by visualizing an actual animal or any direct evidence (e.g. tracks, birdsongs, nests, faeces) were also noted.

Based on climate and weather observations from previous years, the month of May was predicted to be the most suitable time for the survey. Sites were surveyed for ticks from 9th May to 1st June, 2018, preferably during morning hours from 9 to 11 am, as ticks are active and dew is not heavy on the vegetation, which might influence tick attachment to the collection cloth. Each site was surveyed once.

\section{Tick collection and species identification}

Tick collections were performed using the flagging technique with a $1 \mathrm{~m}^{2}$ light-colored flannel cotton cloth, attached to a wooden T-shaped handle, which was dragged over the vegetation and observed for tick presence at every 5 meters passed. The minimum transect was 300 m ${ }^{2}$ per collection. However, no unique transect sizes nor standardized flagging was used as the terrain, weather and vegetation conditions at every chosen area varied and no specific focus on tick density evaluation had been planned. Ticks were removed from the cloth with tweezers, placed into separate glass vials according to stage and sex, and stored at $+4^{\circ} \mathrm{C}$ prior to species identification. The presence of larvae was noted but these were not collected, counted nor included in any analysis of the study. Adults and nymphal ticks were identified individually using a stereomicroscope according to morphological keys [15]. Ambiguous specimens were additionally identified by molecular keys using PCR based on internal transcribed spacer 2 (ITS2) and partial 16S rRNA gene as described previously [10, 16]. Mean abundance (number of nymphal and adult ticks per $100 \mathrm{~m}$ ), as well as index of abundance were calculated as described [17].

\section{Nucleic acid isolation and TBPs screening}

All ticks were individually processed for DNA and RNA isolation by blackPREP Tick DNA/RNA kit (Analytik Jena, Germany). The initial tick lysis step was increased twice in time and the homogenization step was performed twice according to manufacturers' recommendations.

Homogenization was performed using MixerMill MM301 (Retsch, Haan, Germany). Mixing mill cassettes with vials, containing tick homogenate, were flipped over between homogenization steps to assure better milling performance. DNA and RNA solutions were then stored at -20C and 70C, respectively, prior to further individual screening for the presence of TBPs.

All ticks' nucleic acids extracts were analyzed individually. Positive ticks' samples and deionized PCR-grade water were used as positive and negative controls, respectively, at every amplification step. To reduce contamination risk, every procedure, including tick pre-extraction washes, RNA/DNA extraction, PCR reaction mix preparation, DNA/RNA adding step, PCR reaction and gel-electrophoresis were performed in separate rooms.

The initial screening of TBEV RNA, based on the amplification of 3' non-coding region, was performed with primers F-TBE1, R-TBE1 and probe TBE-W [18]. For further sequencing and genotyping, all positive samples were amplified additionally by nested RT-PCR for the partial E protein gene with SuperScript III Reverse Transcriptase kit (ThermoFisher Scientific, USA) and primers described elsewhere [13, 19].

Nested PCR reactions were used for screening and genotyping of BBSL, B. miyamotoi, Anaplasmataceae as well as Rickettsia species identification prior initial screening.

The detection of BBSL and B. miyamotoi DNA was performed by amplification of 245-256 bp long 5S-23S transcribed internal spacer region and 532 bp fragment of $p 66$ gene, respectively $[20,21]$. To confirm $B$. miyamotoi species, p66-positive samples were additionally amplified for 379 bp long $g l p Q$ gene fragment.

Identification of Anaplasmataceae DNA in the tick samples was performed by amplifying 524 bp gene fragment of 16S rRNA gene [10]. For further sequencing analysis, all positive samples were subjected to amplification of $1350 \mathrm{bp}$ long Anaplasmataceae 16S rRNA gene [10] under modified cycling conditions (Supplementary Table 1). Samples positive after initial screening, but negative for 1350 bp long $16 \mathrm{~S}$ rRNA fragment, 
were additionally amplified for a $1300 \mathrm{bp}$ long fragment of heat shock operon groESL gene with primers described elsewhere [22], under modified cycling conditions (Supplementary Table 1).

Rickettsia spp. screening in tick DNA samples was performed with qPCR amplifying 74 bp region of gltA gene [11]. Genotyping of Rickettsia species in positive qPCR samples was performed by sequencing of 667 bp long region of gltA gene, amplified by nested PCR [23]. Samples positive for qPCR, but negative for glt $A$ region, were additionally subjected to PCR amplification of a 769 bp long omp $B$ gene region as described by Roux and Raoult [24] and an 843 bp long region of sca4 gene as described by Igolkina et al. [23].

Detailed information on all PCR reactions, including targets, product size, primer/probe sets and amplification conditions used in the current study are presented in Supplementary Table 1.

All final nested PCR products were visualized by $1 \%$ agarose gel electrophoresis, stained with ethidium bromide.

For genotyping, all final PCR products were subjected to direct Sanger sequencing, performed at Core Facility, Institute of Genomics, University of Tartu.

Genotyping analyses of retrieved sequences were performed using BioEdit and MEGA 7.0 software BLASTN® tools (http://www.ncbi.nlm.nih.gov/BLAST.cgi).

\section{Results \\ Tick sampling}

From the 20 sites visited during the study, ticks were found at 13 sites within the city, and at all 3 peri-urban sites. There were no ticks found in the city central parks Hirvepark and Toompark, von Glehni park, Järve health trails and Sanatooriumi park (sites 5, 6, 14 and 16, respectively) (Figure

1). As tick sampling was not standardized for the collection area and time, the collection results could not be extrapolated to questing tick density in the surveyed regions. However, mean tick abundance and abundance index were calculated for all study sites.

A total of 186 adults and 669 nymphs were collected from over $12000 \mathrm{~m}^{2}$ of vegetation screened at 17 urban and 3 peri-urban sites (Table 1 ). All ticks were identified by morphological criteria and by ITS2 based PCR as I. ricinus except one I. persulcatus collected in Sütiste park.

Among all visited sites, significantly higher numbers of ticks were collected at Estonian Open Air Museum, Tallinn Zoo and Pirita forest park that accounted for $26.4 \%, 24.7 \%$, and $14.3 \%$ of the total number of collected ticks, respectively. Concordantly, the estimated mean abundance of ticks at the urban sites was also the greatest at Estonian Open Air Museum and Tallinn Zoo (18.8 and 17.6, respectively), followed by Pirita forest park (9.8). Among the peri-urban sites, the highest number of collected ticks, as well as the highest abundance rate was observed in the Männiku forest (Table 1).

\section{Pathogen prevalence}

All adults $(\mathrm{n}=186)$ and nymphal $(\mathrm{n}=669)$ ticks were individually screened for the presence of followed tick-borne pathogens: TBEV, $B$. burgdorferi s.I., B. miyamotoi, Anaplasmataceae (Anaplasma, Ehrlichia and Neoehrlichia) and Rickettsia spp. Overall, TBPs were detected at every site where ticks were found, except Harku-Nõmme, although their taxonomic composition and prevalence varied.

The total prevalence of ticks with at least one pathogen was 34.3\% (293/855) (Table 2). Due to non-standardized collections, estimated prevalence rates were calculated only for sites with over 50 adult and nymphal ticks collected and analyzed, that are Pirita forest park, Estonian Open Air Museum, Tallinn Zoo and Männiku. Among these, the site-specific prevalence of TBP-positive ticks was the highest at Estonian Open Air Museum and Tallinn Zoo - 43.8\% and 42.2\%, respectively, followed by Pirita forest park (31.1\%) and peri-urban Männiku forest (18.9\%) (Table 2). For other sites, only the presence of TBPs and the number of ticks tested positive have been noted.

\section{Borrelia burgdorferi (sensu lato)}

B. burgdorferi s.I. was the most prevalent detected TBP. In total, 150 ticks tested positive for the presence of BBSL DNA by 5S-23S based PCR, indicating a $17.5 \%$ prevalence among all analyzed ticks, and $51.2 \%$ among ticks with at least one TBP. BBSL was found in ticks collected at almost every collection site, except Pirita river valley, and Harku-Nõmme. The highest site-specific prevalence was observed at Estonian Open-Air Museum and Tallinn's Zoo - 25.2\% and $22.7 \%$, respectively. Surprisingly, a significantly lower rate was detected in ticks collected in the peri-urban Männiku forest.

Sequence analysis of the 5S-23S intergenic spacer region revealed the presence of three $B$. burgdorferi s.I. genospecies: $B$. afzelii (127/150; $84.7 \%)$, B. garinii (11/150; 7.3\%), B. valaisiana (7/150; 4.7\%) and B. bavariensis (1/150; $0.7 \%)$, while four samples remained unspecified at the 
genospecies level.

Borrelia afzelii was detected in 11 of 13 urban and all sub-urban sites. It was the most prevalent genospecies with rates up to $24.8 \%$ and $21.8 \%$ at Open Air Museum and Tallinn's Zoo, respectively, followed by Pirita forest park (4.9\%) and Männiku (4.1\%) (Table 2). According to the phylogenetic analysis, all $B$. afzelii 5 S-23S spacer region sequences obtained in this study had nucleotide similarity rates within $77.4 \%$ to $99.5 \%$ between each other and were $100 \%$ identical to those previously found to be circulating in Estonian questing and passerine-attached ticks (GenBank accession no. KX418639, KX418638, KX418640), and to other sequences reported from France (acc. no. KY273112, KY273113), Italy (acc. no. MT038899), Slovakia (acc. no. KX906933, KX906945), Taiwan (acc. no. JX649207) and Russia (acc. no. MK118750, AB178349).

The second most prevalent BBSL genospecies detected in urban and peri-urban ticks, although at significantly lower rates, was $B$. garinii, which was detected in 11 ticks, collected at 5 urban sites, with the majority from Pirita forest park (6/122), followed by Tallinn's Zoo (2/211). Single $B$. garinii-positive ticks were detected also at Kadrioru, Ilmarise health trails, and Estonian Open Air Museum (Table 2). The B. garinii 5S-23S IGS sequences of this study showed similarity rates from $79.0 \%$ to $99.5 \%$ between each other and clustered with sequences reported from Estonia (acc. no. KX418634 and KX418637) as well as from Taiwan (acc. no. JX649205), Italy (acc. no. MT038900) Belarus (acc. no. AY772205), Sweden (acc. no. JX909934), Czech (acc. no. AF497993) and Russia (acc. no. MK118761).

Borrelia valaisiana and $B$. bavariensis genospecies were also found, albeit at overall prevalence rates of $<1 \%$. $B$. valaisiana was detected at overall prevalence of $0.8 \%$ (7/855) in ticks collected at Pirita forest park (2/122), Ilmarise health trails (1/37), Stroomi (1/38), Nõmme-Mustamäe $(1 / 30)$ and Sütiste (TalTech) park (2/21). Borrelia bavariensis was detected in a single tick from the suburban site Jägala (Table 2). According to the phylogenetic analysis of 5S-23S sequences of $B$. valaisiana obtained in this study, they were identical to each other and to $B$. valaisiana isolate 122 (acc. no. KX418641) previously detected in Estonian I. ricinus, removed from the Common Blackbird [25], and also to B. valaisiana strains reported from Spain (acc. No. MG245790), Czech Republic (acc.no AF497989) and Italy (acc.No MT038902). The B. bavariensis 5S-23S rRNA sequence retrieved from I. ricinus collected in Jägala was identical to that found in I. ricinus from the Estonian county Läänemaa [8] and also to strain Ir-4370, reported from Stavropol, Russia (acc.no KU672534) and B. bavariensis prototype strain PBi (acc. no FJ546494).

\section{Borrelia miyamotoi}

Borrelia miyamotoi, belonging to the relapsing-fever group Borrelia, was detected in $2.5 \%$ of all analyzed ticks (21/855). This genospecies was found mostly in Estonian Open Air Museum (10/226, 4.4\%) and Tallinn Zoo (8/211, 3.8\%), followed by peri-urban Männiku forest (2/74, 2.7\%). A single B. miyamotoi-positive I. ricinus was also collected from the surroundings of Tallinn Zoo (Table 2). Analysis of the B. miyamotoi partial p66 gene showed that nucleotide sequences of this study are identical to each other and sequences revealed previously in the Estonian tick population [9].

\section{Rickettsiales}

Rickettsia sp. were the second most prevalent bacterial TBP after BBSL: its presence was detected in 13.8\% (118/855) of analyzed tick samples. Prevalence in the study sites ranged between 10.8\% (8/74) in peri-urban Männiku and 18\% (22/122) at Pirita forest park (Table 2). According to phylogenetic analysis of partial gltA gene nucleotide sequences, all Rickettsia positive samples belonged to the $R$. helvetica species. Sequences were identical to each other and sequences previously reported in Estonian Ixodes ticks Katargina et al. [11]. Samples that were sequenced for partial sca 4 and $o m p B$ genes were also classified as $R$. helvetica species and were identical to each other within each gene fragment.

A total of $6.0 \%$ (51/ 855) single analyzed ticks collected at 4 urban and 2 peri-urban sites tested positive for the presence of Anaplasmataceae DNA according to partial 16S rRNA PCR results. The highest prevalence was observed among ticks collected at Tallinn Zoo (24/211, $11.4 \%)$ and Estonian Open Air Museum (18/226, 8.0\%), followed by Pirita forest park with a 4.9\% prevalence (6/122). Single Anaplasmataceaepositive ticks were also collected in the Tallinn's Zoo surrounding area and sub-urban Vääna-Jõesuu and Jägala areas. The analysis of Anaplasmataceae 16S rRNA sequences revealed the presence of two species: A. phagocytophilum $(0.6 \%, 5 / 855)$ and $N$. mikurensis $(5.4 \%, 46 / 855)($ Table 2$)$. At Pirita forest park two ticks out of 122 tested positive for the presence of $A$. phagocytophilum DNA, as did single ticks from three other locations: Open Air Museum, Tallinn Zoo and the sub-urban area of Jägala. 16S rRNA partial nucleotide sequences of $A$. phagocytophilum obtained in this study were $99.7 \%$ - 99.9\% similar to each other. The comparison to previously reported sequences from Estonian questing ticks (acc.no HQ629920, HQ629922, HQ629920) and sequences reported from Russia (acc.no HQ629911), Sweden (acc.no AY527213) and Austria (acc.no JX173652) showed $99.7 \%-100 \%$ similarity

The highest prevalence of $N$. mikurensis was observed in questing ticks collected from Tallinn Zoo (10.9\%, 23/211), followed by Estonian Open Air Museum $(7.5 \%, 17 / 226)$ and Pirita forest park $(3.3 \%, 4 / 122)$. Single $N$. mikurensis-positive ticks were also found in the surrounding area of Tallinn Zoo and peri-urban Vääna-Jõesuu. Sequences of N. mikurensis partial $16 S$ rRNA, retrieved in this study, showed $98.2 \%-99.6 \%$ similarity to GenBank sequences reported previously from Estonian ticks (acc. no KU535862) and 98.1\% - 99.4\% similarity to sequence from Germany (acc. no KU865475) and Russian Western Siberia (acc.no MN736126).

\section{TBEV}

Page 5/15 
According to qRT-PCR results, TBEV was the least common of detected TBPs, detected with in 4 l. ricinus nymphs of all 855 examined individual ticks found at Pirita river valley, Ilmarise health trails, Estonian Open Air Museum and Männiku forest (total prevalence of 0.5\%). Two samples were successfully sequenced and genotyped (Table 2).

According to the analysis of the partial E gene sequence obtained from an I. ricinus tick sample from the Estonian Open Air Museum, it clustered with TBEV-Sib sequences previously detected in Estonian I. persulcatus ticks collected in Eastern Estonia (TBEV isolates Est222 and Est221, accession numbers KT748749 and KT748748, respectively) at an identity rate of $99.8 \%$, and belonging to the Baltic lineage within TBEV-Sib [13, 26]. Another TBEV partial E gene sequence, retrieved from an I. ricinus sample collected at Ilmarise health trails, clustered within the TBEV-Eu subtype with $98.7 \%$ similarity to previously reported Estonian strain Est3476 (acc.no GU183383) and 99.6\% similarity to TBEV strain Latvia-8110 (acc.no. AJ319583).

\section{Mixed infections}

In all, $15.0 \%$ (44/293) of all TBP-positive ticks contained double infections and 4 tick samples tested positive for three tick-borne pathogens $(4 / 293,1.4 \%)$. The most frequently detected TBP combination in double infected ticks was B. afzelii with $N$. mikurensis (18/44) or $R$. helvetica $(14 / 44)$ and these originated mainly from Open Air Museum, Tallinn Zoo and Pirita-Pirita forest park. It is noteworthy that of the 4 TBEV-positive tick samples, 2 were co-infected with bacterial TBP: one tick sample from Estonian Open Air Museum was positive for TBEV-Sib and N. mikurensis, and the TBEV-Eu - positive sample from Männiku was also positive for unspecified BBSL. Of the four tick samples with triple infections, three tested positive for the presence of B. afzelii, R. helvetica and N. mikurensis, and one for B. afzelii, R. helvetica and B. miyamotoi.

\section{Discussion}

More than 30 years have passed since the urbanization of arthropod vectors and the occurrence of tick-borne pathogens within cities and industrial regions were first reported $[27,28]$. Since then, continuous ecologic and climate changes along with socio-demographic drivers have altered tick-associated natural environments resulting in reports of an increase in tick abundance and various tick-borne pathogens in cities, parks, outdoor leisure areas and other urbanized regions across Europe [4, 5, 29, 30, 31]. Furthermore, the northward expansion of $I$. ricinus and the occurrence of $I$. persulcatus to the west and north of its main distribution area may also drive the spread of tick-borne pathogens into new areas, giving rise to new foci as well as affecting public health [32, 33].

This study confirms the occurrence of Ixodes tick species in popular recreational, outdoor sports and leisure areas in the capital and largest city of Estonia, with abundance rates compatible or even exceeding those detected previously in the most endemic foci in the natural environments [34]. The number of ticks collected at different urban and peri-urban locations during this study might not emulate the actual abundance as this study was not focused on tick density and flagging was not highly standardized. It is, however, noteworthy, that a large number of ticks was found in larger, less fragmented forest-type parks with needle- and broad-leaved trees, and underwood with rich litter, as well as signs of the presence of an ample variety of urbanized small and medium-sized mammals such as Apodemus and Myodes rodents, shrews, hedgehogs, ground nesting and feeding birds, foxes and roe deer. Such an environment is a prerequisite for tick survival, development and maintenance. As seen in this study, Zoo, Open Air Museum and Pirita forest park, which are situated in large urban parks with areas similar to natural environments with a variety of small- and medium-sized animal species living there - showed significantly higher tick abundance rates compared to those, similar in vegetation but poorer in animal species and more fragmented in size (Sanatooriumi park, Järve forest health trails, Harku-Nõmme and von Glehni park). As a contrast, the carefully managed Kadriorg park, the largest and most popular park in Tallinn with many mowed open areas, but also rich in landscapes and plant communities with oak and chestnut trees, where rodents, hedgehogs, squirrels and various migratory bird species are abundant, as well as small, well-maintained parks with regularly mowed open grass, such as Hirve and Toompark located in the city center, were extremely poor habitats for Ixodes ticks. These are highly fragmented areas with a high anthropogenic habitat disturbance which might negatively affect tick presence and maintenance. While not focusing on tick density and lacking statistical analysis, our study results are generally in agreement with other European studies, pointing out the negative correlation of tick density towards urbanization rather than in relation to natural hosts [35]. As seen in Zoo and Open Air Museum, and also in the peri-urban Männiku forest, the presence of urbanized synanthropic carnivores, i.e. foxes, or roe-deer together with small animals, suitable environment and vegetation is essential for the maintenance of tick populations.

It is well known that the circulation of TBEV in natural foci is maintained by small rodents, which are competent reservoir hosts, and ticks, that are both hosts and vectors [36]. As many rodent species are well-adapted to a human-affected and urbanized environment, the presence of TBEV foci and therefore, the occurrence of autochthonous human TBE cases even within large cities is possible [37]. According to our earlier studies, TBEV was found in questing ticks at prevalence rates varying from 0.2 to $0.8 \%$ in the $I$. ricinus allopatric area and up to $4.9 \%$ in the areas of $I$. persulcatus co-circulation [13] which is in line with the results of this study as well as with prevalence rates of TBEV in $I$. ricinus in European foci [38]. According to epidemiological data of Estonian Health Board in about 18\% of TBE patients in Harju county had a tick bite history from Tallinn [7]. The results of this study not only confirm the presence of TBEV foci in green areas within the city but also indicate circulation of European and Siberian subtypes of TBEV in I. ricinus ticks within urban and peri-urban areas. The presence of TBEV-Sib in I. ricinus ticks in locations with 
no I. persulcatus co-circulation had also been previously shown [13]; thus, it may be assumed that TBEV-Sib might be potentially spread into I. ricinus distribution areas without the presence of its principal vector, I. persulcatus.

The epidemiological reports of the Estonian Health Board showed that in 2014-2018 up to 19\% of all confirmed Lyme borreliosis patients in Harju county with the known geographical origin of a tick bite, had been bitten by ticks within Tallinn [7]. The presence of four Lyme borreliosis associated species - B. afzelii, B. garinii, B. valaisiana, B. bavariensis - is in correspondence with previous results conducted in Estonia, however positivity rates differed significantly, being two to three times higher than detected earlier [8]. The results of this study are compatible with BBSL overall prevalence rates calculated for Scandinavia, the Balkan peninsula, and Central Europe (15.5\%, 18.5\% and 19.3\%, respectively) [39]. Similar results have also been shown in urban and suburban areas in Switzerland (18\%) and the urban Lazienki Park in Warsaw, Poland (17.3\%) [35, 40]. As seen in Europe and our previous studies, B. afzelii and B. garinii were the most prominent species found in $I$. ricinus ticks. Noteworthy, that in natural sylvatic areas $B$. afzelii and $B$. garinii constituted $56.1 \%$ and $20.3 \%$, respectively, of all Borrelia sp. -positive $I$. ricinus ticks [8], while in urban and peri-urban ticks of this study the same indicators constituted $84.7 \%$ and $7.3 \%$, respectively. A similar disproportion has also been observed in Poland [35], Switzerland [40] and Belgium [41]. Such a divergence might be explained by pathogen dilution-amplification effects in natural vs fragmented urban environments as well as by differences in host availability. Natural forests and other sylvatic areas with little anthropogenic disturbance, fragmentation and transformation are inhabited or visited during migration stops by large amounts and varieties of avian species which might serve as sources of avian-associated TBPs, such as B. garinii and B. valaisiana [42]. Thus, in the terms of anthropopressure, the contact of ticks with birds and a prevalence of avian-associated TBPs is significantly decreased in comparison to natural areas and may lead to a lower presence of $B$. garinii and $B$. valaisiana in urban ticks. In contrast, rodents, which are highly adapted to an urbanized environment, smaller agglomeration-surrounded areas and human interruption, promote sub-adult tick population maintenance, facilitate the frequency of tick-host contacts and trigger an increase and amplification of rodent-associated Borrelia, such as $B$. afzelii [41].

The presence of Borrelia miyamotoi in questing ticks has also been shown for several European countries, including Estonia [9, 43]. In this study, the prevalence rate of $2.5 \%$ in all analyzed $I$. ricinus ticks and a site-specific prevalence from $2.7 \%$ to $4.4 \%$ is in line with prevalence described for suburban France [44], Switzerland [40] and also with our previous results for Valgamaa and Võrumaa counties, where I. ricinus co-circulates with I. persulcatus and the highest positivity rates of B. miyamotoi (2.8\%) in ticks were reported so far [9]. Rodents, especially Myodes and Apodemus, are known reservoirs for B. miyamotoi in Europe and a study of Jahfari et al. [29] also indicated European hedgehogs (Erinaceus europaeus) as reservoirs. As the population density of peridomestic mice and voles is even higher in the urban and peri-urban regions due to favorable breeding and survival factors [45] and as B. miyamotoi, being related to relapsing fever Borrelia, is transovarially transmitted, the higher infection rates in the urban areas versus natural wooded sites may be due to higher amplification rates of this pathogen within urban landscape fragments compared to larger natural woodlands and pastures.

Although Anaplasmataceae species are known to cause a variety of human diseases, only single sporadic cases of human infections have been reported in Estonia so far. Our previous studies indicated the circulation of at least four medically important species within the Anaplasmataceae family in Estonian I. ricinus populations, i.e. A. phagocytophilum (average 1.7\%-2.6\%) [9], N. mikurensis (1.3\%) [10], followed by R. helvetica and R. monacensis [11]. The detection of Rickettsia spp. in urban and suburban I. ricinus ticks has been reported from Germany, the Czech Republic, Poland and Slovakia at rates from 1 to $47 \%[46,47,48,49,50]$. The results of this study showed almost three times higher $R$. helvetica overall positivity rate compared to those observed in questing ticks in natural environments (6.6\%) [11] ; however, the prevalence rate in sub-urban site Männiku corresponds to that of natural tick habitats in Harjumaa county, as reported by Katargina et al. [11]. It is generally agreed upon that $I$. ricinus is the main vector and natural host of $R$. helvetica [30] and as a spotted-fever group Rickettsia, it is transmitted transstadially and transovarially among ticks. Thus, these factors along with high tick abundance in urban green areas may contribute to higher infection rates of this pathogen. Also, urban populations of European hedgehogs, as proposed by a study by Jahfari et al. [29], may play role in a pathogen maintenance in natural cycles in areas influenced by anthropogenic pressure within cities.

Neoehrlichia mikurensis appeared to be also slightly more prevalent in urban I. ricinus ticks compared to those found in the natural I. ricinus allopatric areas with a site-specific prevalence of 3.3\%-10.9\% (average 5.4\%) versus $1.0 \%-9.1 \%$ (average $0.9 \%$ ), respectively. The data of this study are in line with those reported from urban and sylvatic areas in Austria, Sweden and Germany [51, 52, 53] with prevalence rates from 4.2\% to $6.4 \%$. Such a widespread of the pathogen may be connected not only to arthropod vectors but also to reservoir hosts - bank voles and yellownecked mice - which are largely spread and have well-established populations within city shrubbery parks, cemeteries, outdoor activity and recreational places. Some studies also claim that non-rodent species such as hedgehogs, but not insectivores, may also contribute to $N$. mikurensis maintenance in urban and peri-urban green zones and human dwellings $[29,54]$. Since $N$. mikurensis has been associated with human clinical cases with symptoms including fever, malaise, septicemia and weight loss in immunocompromised as well as in healthy persons $[55,56,57]$, the possible emerging status of this pathogen should be considered as a potential risk for public health in sylvatic and urban habitats.

In vector-borne diseases, an infection may only occur if human activity coincides with the activities of animal reservoirs and vectors. Climate change and urbanization, which both lead to environmental and microclimatic landscape composition and land-use changes, may impact every pathogen-host-vector system stage in different ways, thus affecting the whole system. Green infrastructure improvements within the cities 
support human population welfare. However, even patchy urban green areas may provide suitable environmental and microclimatic conditions for ticks, tick-borne pathogens, and their hosts, which in turn, may lead to an increased incidence of tick-borne diseases within the cities. On the other hand, urban heat island effects have a negative impact on tick survival and activity periods, as well as dense fragmentation and human disturbance lead to reduced biodiversity. Although the risk of acquiring a tick bite and being infected with a tick-borne disease in urban recreational sites may vary significantly between locations, it should not be ignored and proper information about the precautions might be considered at least in the most popular outdoor locations.

\section{Conclusion}

The risk of getting a tick bite, bacterial or viral tick-borne disease must not be underestimated even in urban environments as this study showed. Proper precaution measures might be taken into consideration by local authorities as well as by citizens and tourists as those might get a tickborne disease even in green urban recreational zones without going far in the woods.

\section{Abbreviations}

BBSL: Borrelia burgdorferi sensu lato; TBP(s): tick-borne pathogen(s); TBEV: tick-borne encephalitis virus; LB: Lyme borreliosis; TBE: tick-borne encephalitis; TBD: tick-borne disease; ITS2: internal transcribed spacer 2.

\section{Declarations}

\section{Acknowledgements}

The authors would like to thank Larissa Starkova and Reet Rumvolt (National Institute for Health Development, Estonia), for their assistance during laboratory research and Riina Süld for helpful advice and suggestions to manuscript.

\section{Author's contributions}

MV: Methodology, investigation, resources, original draft writing, supervision. OB: validation, investigation, review and editing. JG: conceptualization, methodology, investigation, resources, original draft writing, visualization, supervision, project administration, funding acquisition. All authors read and approved the final manuscript.

\section{Funding}

This work was supported by the supported by the Ministry of Education and Research of Estonia within the project IUT-42-1.

\section{Availability of data and materials}

All additional data associated with this study can be obtained from the corresponding author on reasonable request. Unique nucleotide sequences obtained during this study were submitted to GenBank database under the following accession numbers: MW916612 - MW916613 for TBEV, MW924118 - MW924135 for B. burgdorferi s.I. species, MW924974 - MW924983 for B. miyamotoi, MW924984 - MW925050 for R. helvetica, MW922752 - MW922756 for A. phagocytophilum and MW922757- MW922793 for Neoehrlichia mikurensis. Due to number of identical sequences, especially within $B$. burgdorferi s.I. and $R$. helvetica, only unique sequences were deposited and duplicate sequences were omitted from submission. Samples which nucleotide sequences allowed to perform pathogen genotyping but with partially poor chromatogram or with possible mixed infections of several pathogen species strains were also excluded from depositing.

\section{Ethics approval and consent to participate}

Not applicable.

\section{Consent for publication}

Not applicable.

\section{Competing interests}

The authors declare that they have no competing interests.

\section{References}

1. Medlock JM, Shuttleworth H, Copley V, Hansford KM, Leach S. Woodland biodiversity management as a tool for reducing human exposure to Ixodes ricinus ticks: a preliminary study in an english woodland. J Vector Ecol. 2012;37 2:307-15; doi: 10.1111/j.1948-7134.2012.00232.x. 
https://www.ncbi.nlm.nih.gov/pubmed/23181853.

2. Dale AG, Frank SD. Urban plants and climate drive unique arthropod interactions with unpredictable consequences. Curr Opin Insect Sci. 2018;29:27-33; doi: 10.1016/j.cois.2018.06.001. https://www.ncbi.nlm.nih.gov/pubmed/30551822.

3. Chvostac M, Spitalska E, Vaclav R, Vaculova T, Minichova L, Derdakova M. Seasonal Patterns in the Prevalence and Diversity of Tick-Borne Borrelia burgdorferi Sensu Lato, Anaplasma phagocytophilum and Rickettsia spp. in an Urban Temperate Forest in South Western Slovakia. Int J Environ Res Public Health. 2018;15 5; doi: 10.3390/ijerph15050994. https://www.ncbi.nlm.nih.gov/pubmed/29762516.

4. Kjelland V, Paulsen KM, Rollum R, Jenkins A, Stuen S, Soleng A, et al. Tick-borne encephalitis virus, Borrelia burgdorferi sensu lato, Borrelia miyamotoi, Anaplasma phagocytophilum and Candidatus Neoehrlichia mikurensis in Ixodes ricinus ticks collected from recreational islands in southern Norway. Ticks Tick Borne Dis. 2018;9 5:1098-102; doi: 10.1016/j.ttbdis.2018.04.005.

https://www.ncbi.nlm.nih.gov/pubmed/29678403.

5. Kowalec M, Szewczyk T, Welc-Faleciak R, Sinski E, Karbowiak G, Bajer A. Rickettsiales Occurrence and Co-occurrence in Ixodes ricinus Ticks in Natural and Urban Areas. Microb Ecol. 2019;77 4:890-904; doi: 10.1007/s00248-018-1269-y. https://www.ncbi.nlm.nih.gov/pubmed/30327827.

6. Terviseamet: Nakkushaigustesse haigestumine Eestis 2000-2020. https://www.terviseamet.ee/et/nakkushaigusedmenuu/tervishoiutootajale/nakkushaigustesse-haigestumine (2021). Accessed 15.04.2021.

7. Terviseamet: Communicable Disease Statistics in Estonia. Edited by Jevgenia Epstein and Natalia Kerbo, vol. 17: National Health Board; 2020: 195.

8. Geller J, Nazarova L, Katargina O, Golovljova I. Borrelia burgdorferi sensu lato prevalence in tick populations in Estonia. Parasit Vectors. 2013;6:202; doi: 10.1186/1756-3305-6-202. https://www.ncbi.nlm.nih.gov/pubmed/23837798.

9. Katargina O, Geller J, Alekseev A, Dubinina H, Efremova G, Mishaeva N, et al. Identification of Anaplasma phagocytophilum in tick populations in Estonia, the European part of Russia and Belarus. Clin Microbiol Infect. 2012;18 1:40-6; doi: 10.1111/j.14690691.2010.03457.x. https://www.ncbi.nlm.nih.gov/pubmed/21199155.

10. Ivanova A, Geller J, Katargina O, Varv K, Lundkvist A, Golovljova I. Detection of Candidatus Neoehrlichia mikurensis and Ehrlichia muris in Estonian ticks. Ticks Tick Borne Dis. 2017;8 1:13-7; doi: 10.1016/j.ttbdis.2016.08.010. https://www.ncbi.nlm.nih.gov/pubmed/27720382.

11. Katargina O, Geller J, Ivanova A, Varv K, Tefanova V, Vene S, et al. Detection and identification of Rickettsia species in Ixodes tick populations from Estonia. Ticks Tick Borne Dis. 2015;6 6:689-94; doi: 10.1016/j.ttbdis.2015.06.001. https://www.ncbi.nlm.nih.gov/pubmed/26096853.

12. Katargina O, Geller J, Vasilenko V, Kuznetsova T, Jarvekulg L, Vene S, et al. Detection and characterization of Babesia species in Ixodes ticks in Estonia. Vector Borne Zoonotic Dis. 2011;11 7:923-8; doi: 10.1089/vbz.2010.0199. https://www.ncbi.nlm.nih.gov/pubmed/21395407.

13. Katargina O, Russakova S, Geller J, Kondrusik M, Zajkowska J, Zygutiene M, et al. Detection and characterization of tick-borne encephalitis virus in Baltic countries and eastern Poland. PLoS One. 2013;8 5:e61374; doi: 10.1371/journal.pone.0061374. https://www.ncbi.nlm.nih.gov/pubmed/23650497.

14. Geller J, Nazarova L, Katargina O, Jarvekulg L, Fomenko N, Golovljova I. Detection and genetic characterization of relapsing fever spirochete Borrelia miyamotoi in Estonian ticks. PLoS One. 2012;7 12:e51914; doi: 10.1371/journal.pone.0051914. https://www.ncbi.nlm.nih.gov/pubmed/23251652.

15. Filippova NA. Ixodid Ticks of the Subfamily Ixodidae. vol. 4: Nauka Leningrad; 1977.

16. Caporale DA, Rich SM, Spielman A, Telford SR, 3rd, Kocher TD. Discriminating between Ixodes ticks by means of mitochondrial DNA sequences. Mol Phylogenet Evol. 1995;4 4:361-5; doi: 10.1006/mpev.1995.1033. https://www.ncbi.nlm.nih.gov/pubmed/8747292.

17. Rogovskyy AS, Nebogatkin IV, Scoles GA. Ixodid ticks in the megapolis of Kyiv, Ukraine. Ticks Tick Borne Dis. 2017;8 1:99-102; doi: 10.1016/j.ttbdis.2016.10.004. https://www.ncbi.nlm.nih.gov/pubmed/27771333.

18. Schwaiger M, Cassinotti P. Development of a quantitative real-time RT-PCR assay with internal control for the laboratory detection of tick borne encephalitis virus (TBEV) RNA. J Clin Virol. 2003;27 2:136-45. https://www.ncbi.nlm.nih.gov/pubmed/12829035.

19. Skarpaas T, Golovljova I, Vene S, Ljostad U, Sjursen H, Plyusnin A, et al. Tick-borne encephalitis virus, Norway and Denmark. Emerg Infect Dis. 2006;12 7:1136-8; doi: 10.3201/eid1207.051567. https://www.ncbi.nlm.nih.gov/pubmed/16836835.

20. Fomenko NV, Livanova NN, Borgoiakov V, Kozlova IV, Shulaikina IV, Pukhovskaia NM, et al. [Detection of Borrelia miyamotoi in ticks Ixodes persulcatus from Russia]. Parazitologiia. 2010;44 3:201-11. https://www.ncbi.nlm.nih.gov/pubmed/20795483.

21. Rar VA, Fomenko NV, Dobrotvorsky AK, Livanova NN, Rudakova SA, Fedorov EG, et al. Tickborne pathogen detection, Western Siberia, Russia. Emerg Infect Dis. 2005;11 11:1708-15; doi: 10.3201/eid1111.041195. https://www.ncbi.nlm.nih.gov/pubmed/16318722.

22. Petrovec M, Sumner JW, Nicholson WL, Childs JE, Strle F, Barlic J, et al. Identity of ehrlichial DNA sequences derived from Ixodes ricinus ticks with those obtained from patients with human granulocytic ehrlichiosis in Slovenia. J Clin Microbiol. 1999;37 1:209-10. https://www.ncbi.nlm.nih.gov/pubmed/9854093.

23. Igolkina YP, Rar VA, Yakimenko VV, Malkova MG, Tancev AK, Tikunov AY, et al. Genetic variability of Rickettsia spp. in Ixodes persulcatus/Ixodes trianguliceps sympatric areas from Western Siberia, Russia: Identification of a new Candidatus Rickettsia species. Infect

Page 9/15 
Genet Evol. 2015;34:88-93; doi: 10.1016/j.meegid.2015.07.015. https://www.ncbi.nlm.nih.gov/pubmed/26190452.

24. Roux V, Raoult D. Phylogenetic analysis of members of the genus Rickettsia using the gene encoding the outer-membrane protein rOmpB (ompB). Int J Syst Evol Microbiol. 2000;50 Pt 4:1449-55; doi: 10.1099/00207713-50-4-1449.

https://www.ncbi.nlm.nih.gov/pubmed/10939649.

25. Geller J, Nazarova L, Katargina O, Leivits A, Jarvekulg L, Golovljova I. Tick-borne pathogens in ticks feeding on migratory passerines in Western part of Estonia. Vector Borne Zoonotic Dis. 2013;13 7:443-8; doi: 10.1089/vbz.2012.1054. https://www.ncbi.nlm.nih.gov/pubmed/23590318.

26. Golovljova I, Katargina O, Geller J, Tallo T, Mittženkov V, Vene S, et al. Unique signature amino acid substitution in Baltic tick-borne encephalitis virus (TBEV) strains within the Siberian TBEV subtype. Int J Med Microbiol. 2008;298 1:108-20; doi: https://doi.org/10.1016/j.ijmm.2007.12.004.

27. Daniel M, Cerny V. Occurrence of the tick Ixodes ricinus (L.) under the conditions of anthropopressure. Folia Parasitol (Praha). 1990;37 2:1836. https://www.ncbi.nlm.nih.gov/pubmed/2370031.

28. Korenberg E, Cerny V, Daniel M. Occurrence of ixodid ticks-the main vectors of tick-borne encephalitis virus in urbanized territory. Folia Parasitol (Praha). 1984;31 4:365-70. https://www.ncbi.nlm.nih.gov/pubmed/6510838.

29. Jahfari S, Ruyts SC, Frazer-Mendelewska E, Jaarsma R, Verheyen K, Sprong H. Melting pot of tick-borne zoonoses: the European hedgehog contributes to the maintenance of various tick-borne diseases in natural cycles urban and suburban areas. Parasit Vectors. 2017;10 1:134; doi: 10.1186/s13071-017-2065-0. https://www.ncbi.nlm.nih.gov/pubmed/28270232.

30. Rizzoli A, Silaghi C, Obiegala A, Rudolf I, Hubalek Z, Foldvari G, et al. Ixodes ricinus and Its Transmitted Pathogens in Urban and Peri-Urban Areas in Europe: New Hazards and Relevance for Public Health. Front Public Health. 2014;2:251; doi: 10.3389/fpubh.2014.00251. https://www.ncbi.nlm.nih.gov/pubmed/25520947.

31. Vaculova T, Derdakova M, Spitalska E, Vaclav R, Chvostac M, Rusnakova Taragelova V. Simultaneous Occurrence of Borrelia miyamotoi, Borrelia burgdorferi Sensu Lato, Anaplasma phagocytophilum and Rickettsia helvetica in Ixodes ricinus Ticks in Urban Foci in Bratislava, Slovakia. Acta Parasitol. 2019;64 1:19-30; doi: 10.2478/s11686-018-00004-w. https://www.ncbi.nlm.nih.gov/pubmed/30671773.

32. Jaenson TG, Varv K, Frojdman I, Jaaskelainen A, Rundgren K, Versteirt V, et al. First evidence of established populations of the taiga tick Ixodes persulcatus (Acari: Ixodidae) in Sweden. Parasit Vectors. 2016;9 1:377; doi: 10.1186/s13071-016-1658-3. https://www.ncbi.nlm.nih.gov/pubmed/27370406.

33. Laaksonen M, Sajanti E, Sormunen JJ, Penttinen R, Hanninen J, Ruohomaki K, et al. Crowdsourcing-based nationwide tick collection reveals the distribution of Ixodes ricinus and I. persulcatus and associated pathogens in Finland. Emerg Microbes Infect. 2017;6 5:e31; doi: 10.1038/emi.2017.17. https://www.ncbi.nlm.nih.gov/pubmed/28487561.

34. Värv K, Rumvolt R, Remm J, Katargina O, Geller J, Jaik K, et al. The impact of ecological factors on the abundance of ticks and prevalence of tick-borne pathogens in endemic and non-endemic locations in Estonia. Parasit Vectors. 2021 (in press).

35. Kowalec M, Szewczyk T, Welc-Faleciak R, Sinski E, Karbowiak G, Bajer A. Ticks and the city - are there any differences between city parks and natural forests in terms of tick abundance and prevalence of spirochaetes? Parasit Vectors. 2017;10 1:573; doi: 10.1186/s13071-017-2391-2. https://www.ncbi.nlm.nih.gov/pubmed/29157278.

36. Lindquist L, Vapalahti O. Tick-borne encephalitis. Lancet. 2008;371 9627:1861-71; doi: 10.1016/S0140-6736(08)60800-4. https://www.ncbi.nlm.nih.gov/pubmed/18514730.

37. Makenov M, Karan L, Shashina N, Akhmetshina M, Zhurenkova O, Kholodilov I, et al. First detection of tick-borne encephalitis virus in Ixodes ricinus ticks and their rodent hosts in Moscow, Russia. Ticks Tick Borne Dis. 2019;10 6:101265; doi: 10.1016/j.ttbdis.2019.101265. https://www.ncbi.nlm.nih.gov/pubmed/31447316.

38. Suss J. Tick-borne encephalitis 2010: epidemiology, risk areas, and virus strains in Europe and Asia-an overview. Ticks Tick Borne Dis. 2011;2 1:2-15; doi: 10.1016/j.ttbdis.2010.10.007. https://www.ncbi.nlm.nih.gov/pubmed/21771531.

39. Strnad M, Honig V, Ruzek D, Grubhoffer L, Rego ROM. Europe-Wide Meta-Analysis of Borrelia burgdorferi Sensu Lato Prevalence in Questing Ixodes ricinus Ticks. Appl Environ Microbiol. 2017;83 15; doi: 10.1128/AEM.00609-17. https://www.ncbi.nlm.nih.gov/pubmed/28550059.

40. Oechslin CP, Heutschi D, Lenz N, Tischhauser W, Peter O, Rais O, et al. Prevalence of tick-borne pathogens in questing Ixodes ricinus ticks in urban and suburban areas of Switzerland. Parasit Vectors. 2017;10 1:558; doi: 10.1186/s13071-017-2500-2. https://www.ncbi.nlm.nih.gov/pubmed/29121976.

41. Heylen D, Lasters R, Adriaensen F, Fonville M, Sprong H, Matthysen E. Ticks and tick-borne diseases in the city: Role of landscape connectivity and green space characteristics in a metropolitan area. Sci Total Environ. 2019;670:941-9; doi: 10.1016/j.scitotenv.2019.03.235. https://www.ncbi.nlm.nih.gov/pubmed/30921726.

42. Becker NS, Margos G, Blum H, Krebs S, Graf A, Lane RS, et al. Recurrent evolution of host and vector association in bacteria of the Borrelia burgdorferi sensu lato species complex. BMC Genomics. 2016;17 1:734; doi: 10.1186/s12864-016-3016-4. https://www.ncbi.nlm.nih.gov/pubmed/27632983. 
43. Crowder CD, Carolan HE, Rounds MA, Honig V, Mothes B, Haag H, et al. Prevalence of Borrelia miyamotoi in Ixodes ticks in Europe and the United States. Emerg Infect Dis. 2014;20 10:1678-82; doi: 10.3201/eid2010.131583. https://www.ncbi.nlm.nih.gov/pubmed/25280366.

44. Reis C, Cote M, Paul RE, Bonnet S. Questing ticks in suburban forest are infected by at least six tick-borne pathogens. Vector Borne Zoonotic Dis. 2011;11 7:907-16; doi: 10.1089/vbz.2010.0103. https://www.ncbi.nlm.nih.gov/pubmed/21158500.

45. Maaz D, Krucken J, Blumke J, Richter D, McKay-Demeler J, Matuschka FR, et al. Factors associated with diversity, quantity and zoonotic potential of ectoparasites on urban mice and voles. PLoS One. 2018;13 6:e0199385; doi: 10.1371/journal.pone.0199385. https://www.ncbi.nlm.nih.gov/pubmed/29940047.

46. Silaghi C, Gilles J, Hohle M, Pradel I, Just FT, Fingerle V, et al. Prevalence of spotted fever group rickettsiae in Ixodes ricinus (Acari: Ixodidae) in southern Germany. J Med Entomol. 2008;45 5:948-55; doi: 10.1603/0022-2585(2008)45[948:posfgr]2.0.co;2. https://www.ncbi.nlm.nih.gov/pubmed/18826040.

47. Silaghi C, Hamel D, Thiel C, Pfister K, Pfeffer M. Spotted fever group rickettsiae in ticks, Germany. Emerg Infect Dis. 2011;17 5:890-2; doi: 10.3201/eid1705.101445. https://www.ncbi.nlm.nih.gov/pubmed/21529404.

48. Spitalska E, Boldis V, Derdakova M, Selyemova D, Rusnakova Taragelova V. Rickettsial infection in Ixodes ricinus ticks in urban and natural habitats of Slovakia. Ticks Tick Borne Dis. 2014;5 2:161-5; doi: 10.1016/j.ttbdis.2013.10.002. https://www.ncbi.nlm.nih.gov/pubmed/24342052.

49. Venclikova K, Rudolf I, Mendel J, Betasova L, Hubalek Z. Rickettsiae in questing Ixodes ricinus ticks in the Czech Republic. Ticks Tick Borne Dis. 2014;5 2:135-8; doi: 10.1016/j.ttbdis.2013.09.008. https://www.ncbi.nlm.nih.gov/pubmed/24252265.

50. Welc-Faleciak R, Kowalec M, Karbowiak G, Bajer A, Behnke JM, Sinski E. Rickettsiaceae and Anaplasmataceae infections in Ixodes ricinus ticks from urban and natural forested areas of Poland. Parasit Vectors. 2014;7:121; doi: 10.1186/1756-3305-7-121.

https://www.ncbi.nlm.nih.gov/pubmed/24661311.

51. Glatz M, Mullegger RR, Maurer F, Fingerle V, Achermann Y, Wilske B, et al. Detection of Candidatus Neoehrlichia mikurensis, Borrelia burgdorferi sensu lato genospecies and Anaplasma phagocytophilum in a tick population from Austria. Ticks Tick Borne Dis. 2014;5 2:13944; doi: 10.1016/j.ttbdis.2013.10.006. https://www.ncbi.nlm.nih.gov/pubmed/24345313.

52. Andersson M, Bartkova S, Lindestad O, Raberg L. Co-infection with 'Candidatus Neoehrlichia Mikurensis' and Borrelia afzelii in Ixodes ricinus ticks in southern Sweden. Vector Borne Zoonotic Dis. 2013;13 7:438-42; doi: 10.1089/vbz.2012.1118. https://www.ncbi.nlm.nih.gov/pubmed/23590321.

53. Richter D, Matuschka FR. "Candidatus Neoehrlichia mikurensis", Anaplasma phagocytophilum, and lyme disease spirochetes in questing european vector ticks and in feeding ticks removed from people. J Clin Microbiol. 2012;50 3:943-7; doi: 10.1128/JCM.05802-11. https://www.ncbi.nlm.nih.gov/pubmed/22205824.

54. Silaghi C, Woll D, Mahling M, Pfister K, Pfeffer M. Candidatus Neoehrlichia mikurensis in rodents in an area with sympatric existence of the hard ticks Ixodes ricinus and Dermacentor reticulatus, Germany. Parasit Vectors. 2012;5:285; doi: 10.1186/1756-3305-5-285. https://www.ncbi.nlm.nih.gov/pubmed/23216786.

55. Andreasson K, Jonsson G, Lindell P, Gulfe A, Ingvarsson R, Lindqvist E, et al. Recurrent fever caused by Candidatus Neoehrlichia mikurensis in a rheumatoid arthritis patient treated with rituximab. Rheumatology (Oxford). 2015;54 2:369-71; doi: 10.1093/rheumatology/keu441. https://www.ncbi.nlm.nih.gov/pubmed/25416710.

56. Silaghi C, Beck R, Oteo JA, Pfeffer M, Sprong H. Neoehrlichiosis: an emerging tick-borne zoonosis caused by Candidatus Neoehrlichia mikurensis. Exp Appl Acarol. 2016;68 3:279-97; doi: 10.1007/s10493-015-9935-y. https://www.ncbi.nlm.nih.gov/pubmed/26081117.

57. Welinder-Olsson C, Kjellin E, Vaht K, Jacobsson S, Wenneras C. First case of human "Candidatus Neoehrlichia mikurensis" infection in a febrile patient with chronic lymphocytic leukemia. J Clin Microbiol. 2010;48 5:1956-9; doi: 10.1128/JCM.02423-09. https://www.ncbi.nlm.nih.gov/pubmed/20220155.

\section{Tables}

Table 1. Tick collection sites and tick collection results. 


\begin{tabular}{|c|c|c|c|c|c|c|c|c|c|c|c|}
\hline \multirow{2}{*}{$\begin{array}{l}\text { site } \\
\text { No }\end{array}$} & \multirow[t]{2}{*}{ Name } & \multirow[t]{2}{*}{ Description } & \multirow[t]{2}{*}{ Latitude/longitude } & \multirow{2}{*}{$\begin{array}{l}\mathrm{m} 2 \\
\text { flagged }\end{array}$} & \multicolumn{7}{|c|}{ No. of ticks collected } \\
\hline & & & & & $L^{*}$ & $\mathbf{N}$ & M & $\mathbf{F}$ & Total & $\begin{array}{l}\text { mean } \\
\text { abundance** }\end{array}$ & $\mid A^{\star * *}$ \\
\hline 1 & $\begin{array}{l}\text { Pirita river } \\
\text { valley }\end{array}$ & $\begin{array}{l}\text { riverside with rich } \\
\text { herbal lower } \\
\text { vegetation and } \\
\text { bushes; }\end{array}$ & $59.4574,24.9023$ & 450 & - & 16 & 1 & 1 & 18 & 4.0 & 6.0 \\
\hline 2 & $\begin{array}{l}\text { Pirita forest } \\
\text { park }\end{array}$ & $\begin{array}{l}\text { large urban mixed } \\
\text { forest, with hills and } \\
\text { swamp areas and } \\
\text { rich litter; }\end{array}$ & $59.4604,24.8593$ & 1250 & + & 107 & 7 & 8 & 122 & 9.8 & 40.7 \\
\hline 3 & Kadrioru & $\begin{array}{l}\text { large urban park } \\
\text { with mainly } \\
\text { broadleaved trees; }\end{array}$ & $59.4415,24.7982$ & 300 & - & 4 & 1 & 1 & 6 & 2.0 & 2.0 \\
\hline 4 & $\begin{array}{l}\text { Ilmarise health } \\
\text { trails }\end{array}$ & $\begin{array}{l}\text { large natural-like } \\
\text { urban mixed forest } \\
\text { with swamps }\end{array}$ & $59.3659,24.6666$ & 1400 & + & 30 & 5 & 2 & 37 & 2.6 & 12.3 \\
\hline 5 & Hirve/Toompark & $\begin{array}{l}\text { central city park, } \\
\text { some bushes with a } \\
\text { litter; }\end{array}$ & $59.4336,24.7374$ & 600 & - & - & - & - & - & - & - \\
\hline 6 & von Glehni park & $\begin{array}{l}\text { a park in the large } \\
\text { urban mixed forest }\end{array}$ & $59.3925,24.6577$ & 300 & - & - & - & - & - & - & - \\
\hline 7 & Stroomi & $\begin{array}{l}\text { urban broadleaved } \\
\text { natural-like forest at } \\
\text { the seaside; }\end{array}$ & $59.4372,24.6921$ & 1200 & + & 27 & 6 & 5 & 38 & 3.2 & 12.7 \\
\hline 8 & $\begin{array}{l}\text { Estonian Open } \\
\text { Air Museum }\end{array}$ & $\begin{array}{l}\text { broadleaved and } \\
\text { mixed type urban } \\
\text { semi-forested area } \\
\text { at the seaside; }\end{array}$ & $59.4323,24.6395$ & 1200 & ++ & 175 & 18 & 33 & 226 & 18.8 & 75.3 \\
\hline 9 & $\begin{array}{l}\text { Zoo } \\
\text { surroundings }\end{array}$ & $\begin{array}{l}\text { bushy area, rich in a } \\
\text { litter; }\end{array}$ & $59.4207,24.653$ & 300 & ++ & 7 & 7 & 9 & 23 & 7.7 & 7.7 \\
\hline 10 & $\begin{array}{l}\text { Sütiste forested } \\
\text { park }\end{array}$ & $\begin{array}{l}\text { urban mixed-type } \\
\text { forest }\end{array}$ & $59.3944,24.6899$ & 600 & - & 5 & 3 & 2 & 10 & 1.7 & 10.0 \\
\hline 11 & $\begin{array}{l}\text { Nõmme- } \\
\text { Mustamäe }\end{array}$ & $\begin{array}{l}\text { urban mixed type } \\
\text { forested area }\end{array}$ & $\begin{array}{l}59.38952 \\
24.6745\end{array}$ & 600 & - & 26 & 3 & 1 & 30 & 5.0 & 15.0 \\
\hline 12 & Hiiu grove & mixed semi-forest & $59.3780,24.6778$ & 150 & - & 4 & 3 & 2 & 9 & 60 & 9.0 \\
\hline 13 & Harku-Nõmme & $\begin{array}{l}\text { large forest area, } \\
\text { mixed-type trees but } \\
\text { mainly coniferous; } \\
\text { mossy and needle } \\
\text { litter }\end{array}$ & $59.3874,24.6106$ & 100 & - & 2 & - & 2 & 4 & 4.0 & 4.0 \\
\hline 14 & $\begin{array}{l}\text { Järve health } \\
\text { trails }\end{array}$ & $\begin{array}{l}\text { semi-forested area, } \\
\text { mainly with pine } \\
\text { trees and herbal } \\
\text { lower layer }\end{array}$ & 59.3997, 24.7299 & 600 & - & - & - & - & - & - & - \\
\hline 15 & Tallinn Zoo & $\begin{array}{l}\text { natural-like } \\
\text { broadleaved } \\
\text { forested areas with } \\
\text { a rich lower layer }\end{array}$ & $59.4208,24.6616$ & 1200 & +++ & 158 & 23 & 30 & 211 & 17.6 & 70.3 \\
\hline 16 & $\begin{array}{l}\text { Sanatooriumi } \\
\text { park }\end{array}$ & $\begin{array}{l}\text { semi-forested area, } \\
\text { mainly with pine } \\
\text { trees and herbal or } \\
\text { mossy lower layer }\end{array}$ & $59.3762,24.6638$ & 600 & - & - & - & - & - & - & - \\
\hline \multirow[t]{2}{*}{17} & $\begin{array}{l}\text { Sütiste park } \\
\text { (TalTech) }\end{array}$ & $\begin{array}{l}\text { urban mixed-type } \\
\text { semi-forest }\end{array}$ & $59.3931,24.6811$ & 200 & - & 20 & - & 1 & 21 & 10.5 & 21.0 \\
\hline & URBAN total & & & & & 581 & 77 & 97 & 923 & & \\
\hline $1 \mathrm{su}$ & Männiku & $\begin{array}{l}\text { mixed and } \\
\text { coniferous forest } \\
\text { with a mainly herbal } \\
\text { or mossy lower layer }\end{array}$ & $59.3273,24.6797$ & 400 & - & 63 & 6 & 5 & 74 & 18.5 & 37.0 \\
\hline
\end{tabular}




\begin{tabular}{|c|c|c|c|c|c|c|c|c|c|c|c|}
\hline $2 \mathrm{su}$ & Vääna-Jõesuu & $\begin{array}{l}\text { mixed and } \\
\text { coniferous forest } \\
\text { with a mainly herbal } \\
\text { or mossy lower layer }\end{array}$ & $59.4202,24.354$ & 250 & - & 20 & - & 1 & 21 & 8.4 & 21.0 \\
\hline $3 s u$ & Jägala & $\begin{array}{l}\text { mixed forest with a } \\
\text { rich lower layer of } \\
\text { bushes and grass }\end{array}$ & $59.4234,25.2110$ & 400 & - & 5 & - & - & 5 & 1.3 & 5.0 \\
\hline & PERI-URBAN total & & & & - & 88 & 6 & 6 & 100 & & \\
\hline & TOTAL & & & 12100 & & 669 & 83 & 103 & 855 & & \\
\hline
\end{tabular}

* - L - larvae, $\mathrm{N}$ - nymphs, M - male, $\mathrm{F}$ - female; the presence of larvae has been noted without exact count

** number of ticks per $100 \mathrm{~m}^{2}$;

$\star \star \star$ index of abundance $=$ no. of ticks $/$ all minutes of collection by all collectors $x 60$ (one-hour reduction index) .

Table 2. Tick-borne pathogens detected in urban and peri-urban questing ticks. 


\begin{tabular}{|c|c|c|c|c|c|c|c|c|c|c|c|c|}
\hline \multirow[t]{3}{*}{$\begin{array}{l}\text { Site } \\
\text { No* }\end{array}$} & \multirow[t]{3}{*}{$\begin{array}{l}\text { Location } \\
\text { name }\end{array}$} & \multirow{3}{*}{$\begin{array}{l}\text { No of } \\
\text { TBP } \\
\text { positive } \\
\text { ticks/ } \\
\text { No. ticks } \\
\text { analyzed } \\
(\%)\end{array}$} & \multicolumn{6}{|c|}{ 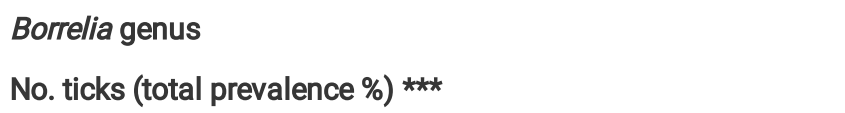 } & \multirow{2}{*}{\multicolumn{3}{|c|}{$\begin{array}{l}\text { Rickettsiales } \\
\text { No. ticks (total prevalence \%) } \\
\star \star \star\end{array}$}} & \multirow[t]{3}{*}{ TBEV } \\
\hline & & & \multicolumn{5}{|c|}{ B. burgdorferi s.l. } & \multirow[t]{2}{*}{ B. miy } & & & & \\
\hline & & & $\begin{array}{l}\text { BBSL } \\
\text { total }\end{array}$ & $\mathrm{BA}^{* *}$ & BG & BV & Bbav & & $\mathrm{Rh}$ & An. ph & N. mik & \\
\hline 1 & $\begin{array}{l}\text { Pirita river } \\
\text { valley }\end{array}$ & $5 / 18$ & & & & & & & $4(1 F)$ & & & \\
\hline 2 & $\begin{array}{l}\text { Pirita forest } \\
\text { park health } \\
\text { trails }\end{array}$ & $\begin{array}{l}38 / 122 \\
(31.1 \%)\end{array}$ & $\begin{array}{l}14 \\
(11.5 \%)\end{array}$ & $6(4.9 \%)$ & $\begin{array}{l}6 \\
(4.9 \%)\end{array}$ & $\begin{array}{l}2 \\
(1.6 \%)\end{array}$ & & & $\begin{array}{l}22 \\
(18.0 \%)\end{array}$ & $\begin{array}{l}2 \\
(1.6 \%)\end{array}$ & $\begin{array}{l}4 \\
(3.3 \%)\end{array}$ & $\begin{array}{l}1 \\
\text { (unsp.) }\end{array}$ \\
\hline 3 & Kadrioru & $1 / 6$ & 1 & & 1 & & & & & & & - \\
\hline 4 & $\begin{array}{l}\text { Ilmarise } \\
\text { health trails }\end{array}$ & $9 / 37$ & 3 & & 1 & 1 & & & 6 & & & - \\
\hline 7 & Stroomi & $7 / 38$ & 5 & 4 & & 1 & & & 3 & & & $\begin{array}{l}1 \\
\text { (unsp.) }\end{array}$ \\
\hline 8 & $\begin{array}{l}\text { Estonian } \\
\text { Open Air } \\
\text { Museum }\end{array}$ & $\begin{array}{l}99 / 226 \\
(43.8 \%)\end{array}$ & $\begin{array}{l}57 \\
(25.2 \%)\end{array}$ & $\begin{array}{l}56 \\
(24.8 \%)\end{array}$ & $\begin{array}{l}1 \\
(0.4 \%)\end{array}$ & & & $\begin{array}{l}10 \\
(4.4 \%)\end{array}$ & $\begin{array}{l}31 \\
(13.7 \%)\end{array}$ & $\begin{array}{l}1 \\
(0.4 \%)\end{array}$ & $\begin{array}{l}17 \\
(7.5 \%)\end{array}$ & - \\
\hline 9 & $\begin{array}{l}\text { Zoo } \\
\text { surroundings }\end{array}$ & $8 / 23$ & 4 & 3 & & & & 1 & 3 & & 1 & $\begin{array}{l}1 \\
(0.4 \%) \\
\text { (TBEV- } \\
\text { Sib) }\end{array}$ \\
\hline 10 & $\begin{array}{l}\text { Sütiste } \\
\text { forested park }\end{array}$ & $1 / 10$ & 1 & 1 & & & & & & & & - \\
\hline 11 & $\begin{array}{l}\text { Nõmme- } \\
\text { Mustamäe }\end{array}$ & $1 / 30$ & 1 & & & 1 & & & & & & - \\
\hline 12 & Hiiu grove & $3 / 9$ & 3 & 3 & & & & & 1 & & & - \\
\hline 13 & $\begin{array}{l}\text { Harku- } \\
\text { Nõmme }\end{array}$ & $0 / 4$ & & & & & & & & & & - \\
\hline 15 & Tallinn Zoo & $\begin{array}{l}89 / 211 \\
(42.2 \%)\end{array}$ & $\begin{array}{l}48 \\
(22.9 \%)\end{array}$ & $\begin{array}{l}46 \\
(21.8 \%)\end{array}$ & $\begin{array}{l}2 \\
(0.9 \%)\end{array}$ & & & $\begin{array}{l}8 \\
(3.8 \%)\end{array}$ & $\begin{array}{l}32 \\
(15.2 \%)\end{array}$ & $\begin{array}{l}1 \\
(0.5 \%)\end{array}$ & $\begin{array}{l}23 \\
(10.9 \%)\end{array}$ & - \\
\hline 17 & $\begin{array}{l}\text { Sütiste park } \\
\text { (TalTech) }\end{array}$ & $5 / 21$ & 4 & 2 & & 2 & & & 1 & & & - \\
\hline $1 \mathrm{su}$ & Männiku & $\begin{array}{l}14 / 74 \\
(18.9 \%)\end{array}$ & $4(5.7 \%)$ & $3(4.1 \%)$ & & & & $\begin{array}{l}2 \\
(2.7 \%)\end{array}$ & $\begin{array}{l}8 \\
(10.8 \%)\end{array}$ & & & - \\
\hline $2 \mathrm{su}$ & $\begin{array}{l}\text { Vääna- } \\
\text { Jõesuu }\end{array}$ & $11 / 21$ & 3 & 2 & & & & & 7 & & 1 & $\begin{array}{l}1 \\
(1.4 \%) \\
\text { (TBEV- } \\
\text { Eu) }\end{array}$ \\
\hline 3 su & Jägala & $2 / 5$ & 2 & 1 & & & 1 & & & 1 & & - \\
\hline & TOTAL & $\begin{array}{l}293 / 855 \\
(34.3 \%)\end{array}$ & $\begin{array}{l}150 / 855 \\
(17.5 \%)\end{array}$ & $\begin{array}{l}127 / 150 \\
(84.7 \%)\end{array}$ & $\begin{array}{l}11 / 150 \\
(7.3 \%)\end{array}$ & $\begin{array}{l}7 / 150 \\
(4.7 \%)\end{array}$ & $\begin{array}{l}1 / 150 \\
(0.7 \%)\end{array}$ & $\begin{array}{l}21 / 855 \\
(2.5 \%)\end{array}$ & $\begin{array}{l}118 / 855 \\
(13.8 \%)\end{array}$ & $\begin{array}{l}5 / 855 \\
(0.6 \%)\end{array}$ & $\begin{array}{l}46 / 855 \\
(5.4 \%)\end{array}$ & $\begin{array}{l}4 / 855 \\
(0.5 \%)\end{array}$ \\
\hline & & & & $\begin{array}{l}127 / 855 \\
(14.9 \%)\end{array}$ & $\begin{array}{l}11 / 855 \\
(1.3 \%)\end{array}$ & $\begin{array}{l}7 / 855 \\
(0.8 \%)\end{array}$ & $\begin{array}{l}1 / 855 \\
(0.1 \%)\end{array}$ & & & & & \\
\hline
\end{tabular}

* Sites with no ticks collected were excluded

** BBSL - B. burgdorferi s.I., BA - B. afzelii, BG- B. garinii, BV - B. valaisiana, Bbav - B. bavariensis, Bmiy - B. miyamotoi, Rh - R. helvetica, An. ph - A. phagocytophilum, N. mik - N. mikurensis, TBEV- tick-borne encephalitis virus

*** Due to non-standardized collections, estimated prevalence rates were calculated only for sites with a total over 50 of adult and nymphal ticks collected and analyzed

Figures 


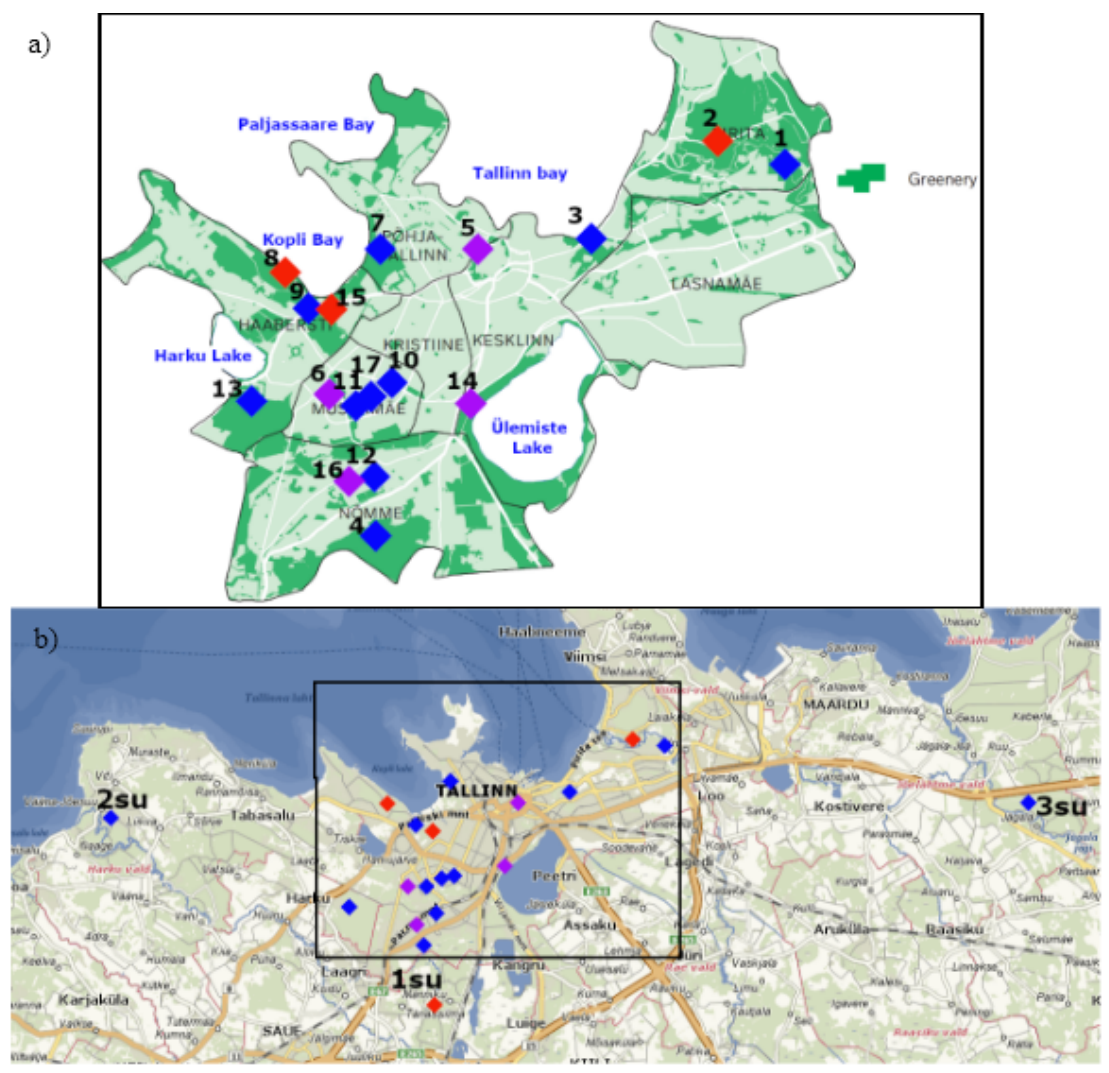

Figure 1

Tick collection sites: a) urban collection sites, located in green areas within the city (Tallinn green areas map retrieved Jan. 21, 2021, https://www.tallinn.ee/est/statistika/Tallinna-tervisestatistika) and b) all tick collection sites. Purple marks represent places with no ticks collected, red - sites with over 50 ticks collected and blue with 1 to 49 ticks collected. Site names according to numbers are as follows: 1 - Pirita river valley, 2- Pirita forest park, 3 - Kadrioru park, 4- Ilmarise health trails, 5- Hirve and Toompark, 6- von Glehni park, 7- Stroomi, 8- Estonian Open Air Museum, 9-Zoo surroundings, 10 - Sütiste park, 11- Nõmme-Mustamäe, 12- Hiiu grove, 13- Harku-Nõmme, 14- Järve health trails, 15- Tallinn's Zoo, 16-Sanatooriumi park, 17- Sütiste park (TalTech), 1su- Männiku, 2su- Vääna-Jõesuu, 3su- Jägala. Note: The designations employed and the presentation of the material on this map do not imply the expression of any opinion whatsoever on the part of Research Square concerning the legal status of any country, territory, city or area o bbnhir of its authorities, or concerning the delimitation of its frontiers or boundaries. This map has been provided by the authors.

\section{Supplementary Files}

This is a list of supplementary files associated with this preprint. Click to download.

- TalTickSupplementarytable1methods.docx

- taltickgraphabstract.jpg 